УДК 631.319:631.3

DOI: $10.35887 / 2305-2538-2021-3-31-39$

КРАТКИЙ АНАЛИЗ ОСНОВНЫХ ТЕХНОЛОГИЙ И ОРУДИЙ ДЛЯ ОБРАБОТКИ ПОЧВЫ

\author{
${ }^{1}$ Швари Анатолий Адольфович \\ ${ }^{1}$ Башкирев Анатолий Петрович \\ ${ }^{1}$ Таныгин Олег Федорович \\ ${ }^{1}$ Лукин Сергей Геннадвевич
}

${ }^{1}$ ФБОУ ВО «Курская государственная сельскохозяйственная академия им. И.И. Иванова»

Реферат. Дан анализ различных технологий обработки почв, рассмотрены конструктивнье u технологические характеристики почвообрабатывающих орудий на примере отвальной, безотвальной и поверхностной технологий, отмечена тенденция снижения роли энергоемкой плужной обработки, показаны качественные показатели работы орудий с пассивньли и активными рабочими органами. Бесприводные ротаџионные орудия с горизонтальной осью вращения, представляющие собой, две батареи игольчатых дисков, соединенных между собой изепной передачей с передаточным коэффициентом около 3, и являются предметом изучения. Они выполняют агротребования поверхностной обработки почвы с минимальным тяговым сопротивлением. Исследована динамика и физическая сущнность работы рыхлителя. Рассмотрены силь, действующие на него. Установлено, что касательная сила реактивного момента, обеспечивающего равновесие системы, у орудий с пассивными рабочими органами увеличивает тяговое сопротивление необходимое для перемещения рыхлителя, а у рыхлителя уменьшает. Ротационные орудия, работающие на принципе движения со скольжением, позволяют снизить тяговое усилие, необходимое для перемещения орудия как за счет снижения скорости резания в сравнении с поступательной, так и изменением направления действия касательной силь реактивного момента. Установлено, что для более широкого использования орудий с ротационными рабочими органами, движущциися со скольжением необходимо идти по пути усовершенствования конструкции рабочих органов.

Ключевые слова: обработка почвы, технологии, орудия, рабочие органы, ротационный бесприводный рыхлитель-измельчитель.

\title{
BRIEF ANALYSIS OF BASIC TECHNOLOGIES AND EQUIPMENT FOR TILLAGE
}

\author{
${ }^{1}$ Schwartz Anatoly \\ ${ }^{1}$ Bashkirev Anatoly \\ ${ }^{1}$ Tanygin Oleg \\ ${ }^{1}$ Lukin Sergey
}

\section{${ }^{I}$ FSBEI HE "Kursk State Agricultural Academy”}

\begin{abstract}
An analysis of various soil cultivation technologies is given, the design and technological characteristics of tillage tools are considered using the example of moldboard, moldboardless and surface technologies, a tendency towards a decrease in the role of energy-intensive plowing is noted, and the qualitative indicators of the work of tools with passive and active working bodies are shown. Nonpowered rotary tools with a horizontal axis of rotation, which are two batteries of needle discs connected by a chain drive with a gear ratio of about 3, are the subject of study. They fulfill the agricultural requirements for surface tillage with minimal traction resistance. The dynamics and physical nature of the work of the ripper have been investigated. The forces acting on it are considered. It has been established that the tangential force of the reactive moment, which ensures the equilibrium of the system, increases the traction resistance required for the ripper movement for tools with passive working bodies, and decreases for the ripper. Rotary tools, operating on the principle of sliding motion, can reduce the tractive effort required to move the tool both by reducing the cutting speed in comparison with the translational one, and by changing the direction of the tangential force of the reactive moment. It has been established that for a wider use of tools with rotary working bodies moving with sliding, it is necessary to follow the path of improving the design of working bodies.
\end{abstract}

Keywords: tillage, technologies, implements, working bodies, rotary non-power ripper-chopper. 
Введение. В настоящее время в практике сельскохозяйственного производства появился целый комплекс технологий: экстенсивные, интенсивные, индустриальные, почвозащитные, влагосберегающие, интегрированные, альтернативные, биологические, адаптивные, экологически чистые и другие.

Однако при любой технологии присутствует обработка почвы, основные задачи которой состоят в создании благоприятных условий для роста и развития сельскохозяйственных культур.

Исходя из агротехнологического назначения, различают следующие группы почвообрабатывающих машин:

- машины и орудия для основной обработки (отвальной, безотвальной);

- орудия для поверхностной обработки почв (включающие бороны дисковые, культиваторы и ротационные орудия);

- комбинированные орудия (машины).

Самую обширную группу для отвальной обработки почв составляют плуги общего назначения, которые могут быть прицепные, навесные и полу- навесные, а количество корпусов различной конструкции - от одного до 9.

Анализ материала показал, что отечественные образцы плугов практически не уступают зарубежным по технико-экономическим показателям.

Положительные качества, позволившие плугу занять ведущее место среди почвообрабатывающих орудий, заключается в удовлетворительном крошении пласта почвы, борьбе с засоренностью полей, сравнительно небольшом тяговом сопротивлении, высокой надежности, малой материалоемкости, простоте конструкции и т.д.

Однако, плуг имеет ряд как технологических, так и конструктивных недостатков. Плуг не выполняет основного требования почвозащитного земледелия - не оставляет стерню на поверхности поля. Ассиметричное расположение рабочих органов приводит к нерациональному использованию тягового усилия тракторов и увеличению длины орудия. Техническим несовершенством плугов является незначительная ширина захвата и большая длина, что не позволяет создавать на их базе комбинированных агрегатов, совмещающих 4-5 и более операций.

Известно, что ни одно из орудий с пассивными рабочими органами не может подготовить почву под посев за один проход. После них, как правило, требуется дополнительное изменение верхнего слоя пахотного горизонта на глубину заделки семян.

Например, исследования, проводимые в донском зональном НИИСХ [1] показали, что ни одно из испытываемых орудий серийного производства - плуги, плоскорезы и тяжелые дисковые бороны не дали требуемой обработки.

Из-за некачественной обработки почвы сошники сеялки не обеспечивают заделку семян на заданную глубину. Семена, попадая между крупными комками, плохо контактируют с почвой, что приводит к снижению всхожести семян и урожайности. Поэтому, как у нас в стране, так и за рубежом ставится вопрос о сокращении плужной обработки $[2,3]$.

Предпринимаются попытки устанавливать на плужные корпуса свободно вращающиеся рабочие органы. Результаты исследований не выявили преимущества комбинированных плугов с рабочими органами пассивного вращения ни по тяговому сопротивлению, ни по качеству обработки почвы[4].

Более совершенным направлением признано применение на плугах ротационных рабочих органов с активным приводом, что способствует снижению тягового сопротивления и более полной загрузке современных энергонасыщенных тракторов.

Низкое качество изготовления рабочих органов влияет на технологические показатели обработки почвы. Особенно это заметно на примере плугов. В период приработки отвалов корпусов, которые в нашей стране изготавливают из черного проката, из-за залипания рабочей поверхности корпусов расход топлива повышается на 15-20\%, а пласт плохо оборачивается. Период приработки отвалов на сырых глинистых почвах может растянуться на весь пахотный сезон $[5,6]$.

Для снижения энергоемкости вспашки эффективно применение шлифованных отвалов, изготовляемых из твердых специальных сталей. Это позволяет снизить тяговое сопротивление рабочих органов плуга до 10\%. Перспективно применение полимерных отвалов типа фторопласт обеспечивающих уменьшение тягового сопротивления плуга на $30 \%$.

Ведутся работы по созданию фронтальных и оборотных плугов. В отечественном машиностроение наметилась тенденция создания модульно-блочных унифицированных узлов и 
агрегатов, что позволяет упростить как изготовление различных типов машин, так и их эксплуатацию и ремонт. Так по данным ВИМа только применение модульных унифицированньгх плугов и комбинированных безотвальных агрегатов позволит сократить номенклатуру машин до $50 \%$, уменьшить трудоемкость техобслуживания на 30\% и снизить расход топлива на 12\%[7].

Для безотвальной обработки почвы выпускаются дисковые орудия, чизельные плуги и культиваторы, глубокорыхлители, плоскорезы и фрезы. Орудия, применяемые для безотвальной обработки, экономичнее и производительнее отвальных плугов.

Все большее распространение получает чизельная обработка почвы. Чизельные орудия менее энергоемки, более производительны и обеспечивают существенную экономию прямых затрат при возделывании сельскохозяйственных культур.

На базе ранее серийно выпускаемого чизельного плуга ПЧ-4,5 производится семейство чизельных глубокорыхлителей, обрабатывающих безотвально почву на глубину до 0,7 м.

Английская фирма «Ай-Си-Ай» разработала оригинальную конструкцико плуга-рыхлителя для безотвальной обработки «Параплау», представляющего собой комбинацию чизеля и плуга

Плуг-рыхлитель получил наибольшее распространение на почвах, подверженных водной и ветровой эрозии и там, где внедрение интенсивного земледелия, с использованием плужной обработки, привело к снижению плодородия почв вследствие разрушения их структуры. Эффективность работы данного орудия проверена в условиях ОППХ ВНИИЗ и ЗПЭ[8,9].

Орудия для безотвальной обработки в основном оснащены плоскорезными рабочими органами. В отличие от плугов плоскорезы обладают меньшей длиной при значительно большей ширине захвата.

Широкое внедрение плоскорезов в практику земледелия сдерживается рядом проблем, возникающих при их эксплуатации. Это повышенная засоренность посевов, недостаточное крошение и неустойчивость хода рабочих органов по глубине обработки при работе на тяжелых почвах.

Проведенные нами исследования и внесенные конструктивные изменения в широкозахватные шарнирно-сочлененные культиваторы позволили повысить устойчивость глубины хода рабочих органов боковых секций [9].

Для поверхностной (мульчирующей) обработки почвы в нашей стране и за рубежом нашли применение орудия, оснащенные дисковыми рабочими органами. Они с успехом используются как для лущения стерни, так и для подготовки почвы под посев. Положительной особенностью дисковых орудий являются их малые габариты и возможность совмещения нескольких технологических операций

Рабочими органами борон являются сферические диски сплошные или вырезные и игольчатые диски.

В качестве противоэрозийного орудия в системе почвозащитного земледелия используется дисковая игольчатая борона БИГ-ЗА.

Большую группу почвообрабатывающих машин как для основной, так и дополнительной обработки почвы составляют прицепные и навесные культиваторы с рабочей шириной захвата до 10 м. В зависимости от возделываемой культуры и агрофона севооборота используются клиновидные, стрельчатые и долотообразные рабочие органы на жестких, подпружиненных или пружинных стойках и органично сочетаются в комбинированных орудиях $[10,11,12]$.

Высокое качество крошения почвы обеспечивают орудия с активными рабочими органами. Однако, они обладают высокой энергоемкостью процесса. Дисковые рабочие органы, имеющие большую площадь скалывания и перемещение частиц по рабочей поверхности оказывают значительное влияние на разрушение почвенной структуры и до 70\% измельчают и засыпают стерню и способствуют развитию эрозионных процессов[13,]. Кроме этого, применение дисковых борон не снижает трудозатрат на единицу обрабатываемой площади.

Орудие с пассивными рабочими органами имеет высокую энергоемкость. Например, плоскорезные лапы шириной 35 см при глубине обработки 22 см и скорости движения 1,45 м/с обладают удельным тяговым сопротивлением 6,4 H/cм² [14]. Борона БИГ-3 при скорости 2,64 м/с имеет удельное тяговое сопротивление $3,96 \mathrm{H} / \mathrm{cm}^{2}[15,16]$.

Удельное тяговое сопротивление таких орудий незначительно увеличивается с увеличением скорости. Например, по данным Р.Ф. Зиязетдинова [17] тяговое сопротивление с увеличением скорости движения увеличивается в среднем на 5,0-6,5\% на каждый метр увеличения скорости, в то время как у плуга это приращение равно $53 \%[18,19]$. 
Таким образом, орудия с игольчатыми дисками обладающие малой энергоемкостью, способны обеспечивать высокое качество крошения почвы. Степень крошения почвы бороной БИГ-3 достигает $75-86 \%$ [20].

Все более широкое применение при поверхностной обработке находят ротационные орудия с вертикальной и горизонтальной осью вращения рабочих органов. Однако привод вертикальных рабочих органов, осуществляемый от ВОМ трактора, усложняет конструкцию и снижает его надежность. Кроме того, это орудие используется только для дополнительной обработки легких и средних почв.

Особый интерес представляет конструкция ротационного бесприводного орудия с горизонтальной осью вращения игольчатых дисков. Конструкция включает две батареи игольчатых дисков соединенных между собой цепной передачей с передаточным коэффициентом около 3. Это позволяет добиться высокой степени крошения почвы $[21,22]$.

Простота конструкции, технологическая надежность, высокая производительность позволяют предположить, что такие орудия займут прочное положение среди почвообрабатывающих орудий как за рубежом, так и в нашей стране [23]

Анализ и обсуждение. Одним из основных направлений развития почвообрабатывающих машин является повышение их производительности и снижение механических воздействий на почву. Как правило, производительность зависит от ширины захвата орудия и скорости его движения, а качество крошения - от способа воздействия рабочих органов на почву. Повышение производительности агрегатов путем увеличения ширины захвата орудия связано с увеличением материалоемкости агрегатов, что снижает их эксплуатационные качества. Повышение производительности путем роста скоростей, вызывает резкое увеличение тягового сопротивления. В этом случае сопротивление почвы действию рабочего органа обусловлено не только деформацией пласта, но и сообщение ему кинетической энергии. Увеличение тягового сопротивления рабочего органа с ростом скорости происходит за счет силы $R a$ [24]

$$
R a=\varepsilon_{\circ} a \mathrm{~B} V^{2} \mathrm{~b}
$$

где $\varepsilon$ - скоростной коэффициент, зависящий от свойств и параметров рабочего органа; $a$ и $в$ высота и ширина подрезаемого пласта; V - скорость движения рабочего органа.

Из этой зависимости следует, что с увеличением скорости сопротивление $R a$ растет по параболе.

Создание скоростных рабочих органов путем совершенствования их геометрической формы позволило, в отдельных случаях, повысить рабочие скорости с 5-6 до 8-9 км/ч [25,26] .

В настоящее время существуют орудия, рабочие органы которых воздействуют на почву со скоростью, равной поступательной скорости агрегата (пассивные) или со скоростью превышающей ее (активные). Например, энергоемкость фрезерования почвы в 2-3 раза выше, чем при вспашке [27]. Кроме того рабочие органы фрезерных почвообрабатывающих орудий, при высоком качестве крошения почвы, быстро изнашиваются. Пассивные рабочие органы не обеспечивают высокого качества крошения почвы и требуют выполнения нескольких технологических приемов[28].

Одним из перспективных направлений развития почвообрабатывающих машин могут служить орудия с ротационными рабочими органами, в виде игольчатых дисков, движущимися со скольжением [29].

По данным предыдущих исследований ВНИИЗиЗПЭ безприводные орудия с ротационными рабочими органами, движущимися со скольжением, обладают высоким качеством крошения почвы и относительно малой энергоемкостью процесса. Это снижает механическое воздействие на почву. Орудие подобного типа впервые включено в систему на 1981-1990гг. Возможности таких орудий использованы далеко не полностью и требуют тщательной теоретической и экспериментальной проверки.

Установлено, что скорость резания при движении со скольжением уменьшается, с уменьшением коэффициента торможения. Это обусловливает снижение энергоемкости процесса [30]. Из анализа динамики рыхлителя следует, что сила $P$, необходимая для перемещения рыхлителя равна (рисунок 1),

$$
\mathrm{P}=\frac{1}{2 g}\left[3 P_{1}+3 P_{2}\left(\frac{1}{\eta}\right)^{2}+2 P_{\text {об }}\right] \ddot{\mathrm{x}}+\frac{N_{1} f_{X_{1}}}{r_{1}}+\frac{N f_{X}}{r_{1}} \cdot \frac{1}{\eta}+F_{p}\left(1-\frac{1}{\eta}\right)-F_{p}\left(1-\frac{1}{\eta}\right) \frac{1}{\eta} \cdot K,
$$


где первое слагаемое представляет собой силу $F_{u}$ инерции рыхлителя; второе и третье - силы $F_{m \kappa}^{\prime}$ и $F_{m \kappa}$ трения качения, соответственно, передней и задней батарей; выражение $F_{p}\left(1-\frac{1}{\eta}\right)$ характеризует усилие $F_{p}$, возникающее на рабочей батарее при обработке почвы; последнее выражение $F_{p}\left(1-\frac{1}{\eta}\right) \frac{1}{\eta} \cdot$ К -есть касательное усилие $F^{\prime}$, обеспечивающее реактивный момент для торможения рабочей батареи, вектор силы $F^{\prime}$ направлен в сторону движения и снижает общее тяговое сопротивление рыхлителя необходимое для его перемещения.

Экспериментальные исследования показали, что величина силы $F^{\prime}$ составляет 8-12\% от общего сопротивления на рабочей батарее.

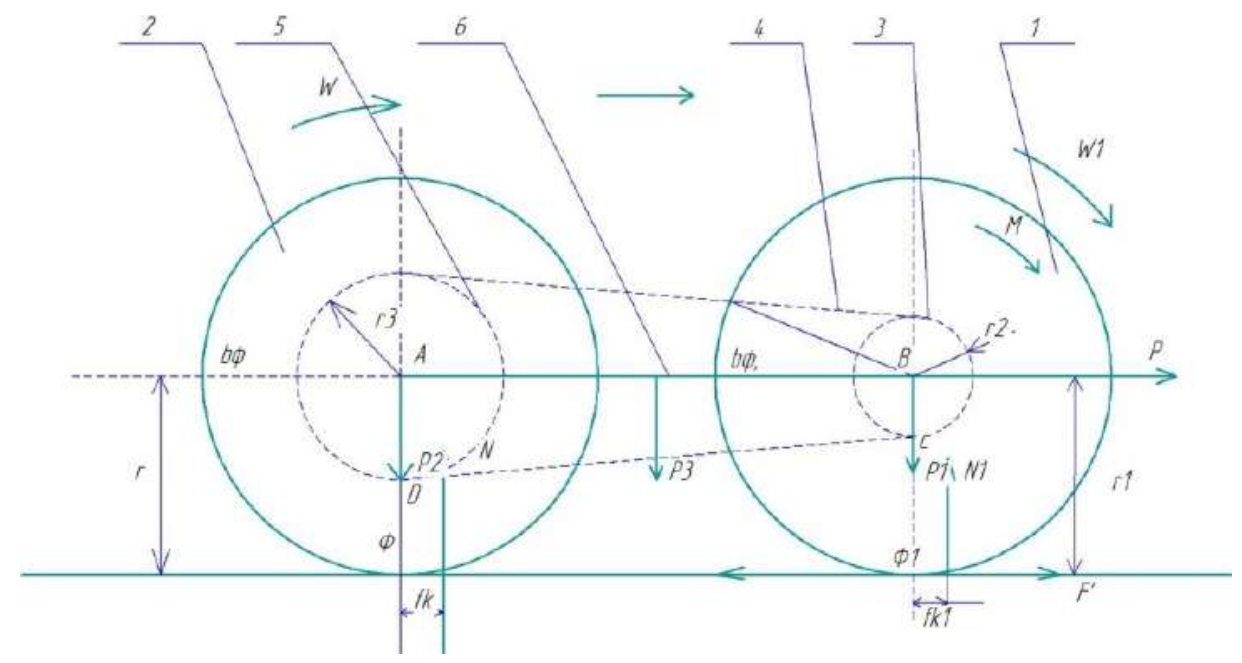

Рисунок 1 - Схема к определению сил, возникающих при кинематическом несоответствии колёс

Рассмотрим физическую сущность работы рыхлителя.

Установлено, что усилие на рабочую батарею 2 в результате действия силы $P$ передается по нижней ветви СД цепи. Тогда рама 6, звездочки 3 и 5 и нижняя ветвь СД цепи образуют четырехзвенный механизм АВСД (см. рисунок 1).

Поскольку сопротивление перекатыванию батарей представляет меньший интерес и с целью наглядности представим игольчатые диски в виде отдельных вертикально расположенных зубьев 1 и 2 длиной $r_{l}$ и $r$ (рисунок 2).

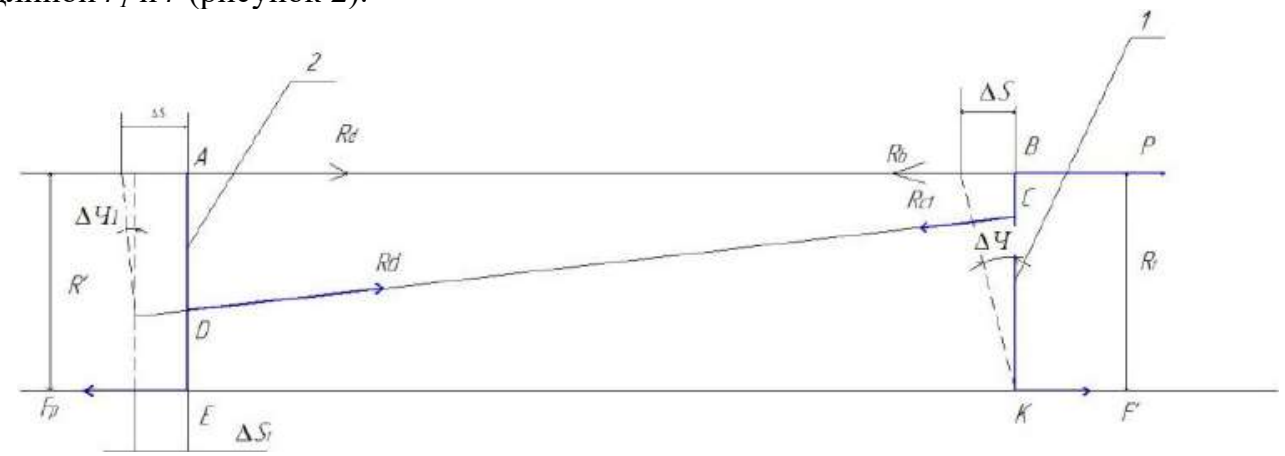

Рисунок 2 - Схема сил, действующих на рыхлитель

Согласно работы рыхлителя передний диск должен двигаться без скольжения и буксования. Следовательно, для установившегося движения при перемещении рыхлителя на бесконечно малое расстояние $\Delta S$ передний зуб 1 повернется вокруг (условно принятого) неподвижного шарнира на бесконечно малый угол $\Delta \phi$. При условии $r_{l}=r$ и $\frac{A D}{B C}=\eta$ (здесь АД и ВС - радиусы звездочек, 
соответственно 3 и 5) зуб 2 повернется на бесконечно малый угол $\Delta \phi=\frac{\Delta \phi_{1}}{\eta}$, а его конечная точка Е переместится на величину $\Delta S_{1}=\frac{\Delta S}{\eta}$.

Уменьшение тягового сопротивления на величину $F^{\prime}$ можно пояснить на примере работы орудий с пассивными рабочими органами, например, культиваторной или плоскорезной лапы (рисунок 2).

В результате такого перемещения в точке $\mathrm{E}$ возникнет сила $F_{p}$ трения скольжения, направленная в обратную сторону действия силы $P$. Сила $F_{p}$ является полезной силой, которая возникает в результате крошения почвы. Эта сила $F_{p}$, вызывает равные и навстречу направленные реакции $R_{\partial}$ и $R_{c}$ в нижней ветви цепи. Одновременно возникают равные и противоположно направленные реакции $R_{a}$ и $R_{b}$, соответственно, в шарнирах А и В и реакция $F^{\prime}$ в шарнире К, направленная в сторону действия внешней активной силы $P$. Для данной системы силы $P, F_{p}$ и $F^{\prime}$ будут внешними. Тогда усилие, необходимое для преодоления силы $F_{p}$, равно

$$
P=F_{p}-F^{\prime}
$$

Но, согласно зависимости (2) сила $F^{\prime}$ определяется

$$
F^{\prime}=F_{p}\left(1-\frac{1}{\eta}\right) \frac{1}{\eta} \cdot \mathrm{K}
$$

т.е. с увеличением $\eta$ сила убывает, и при $\eta=\infty$ когда рабочие органы заторможены, она равна нулю.

Кроме того, сила $F_{p}$ прямо пропорциональна коэффициенту скольжения $\left(1-\frac{1}{\eta}\right)$, следовательно:

$$
\mathrm{P}=F_{p}\left(1-\frac{1}{\eta}\right) \cdot\left(1-\frac{1}{\eta}\right) \cdot \mathrm{K}=F_{P}\left(1-\frac{1}{\eta}\right)^{2} \cdot K,
$$

Сущность уменьшения силы $F_{p}$ заключается в том, что игольчатый диск имеет скорость движения больше, чем скорость резания.

На рабочей поверхности клина возникает результирующая сила $R$ элементарных сопротивлений почвы, направленная под некоторым углом $\psi$ к направлению движения. Для того, чтобы в процессе движения система находилась в равновесии, внешнюю активную силу Р необходимо приложить или по линии действия результирующей силы (см. рисунок 3 а) или установить дополнительное опорное колесо, обеспечивающее реактивный момент, в случае если $\mathrm{P}$ направлена параллельно линии движения (см. рисунок 3б).

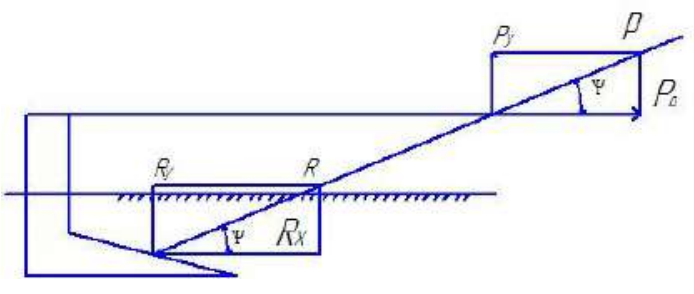

$\mathrm{a}$

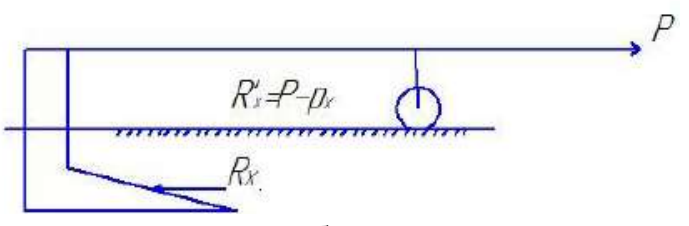

6

Рисунок 3 - Схема сил, действующих на пассивные рабочие органы

Тогда в первом случае для преодоления горизонтальной составляющей $R_{a}$ необходимо приложить внешнюю силу $P=\frac{R_{x}}{\cos \psi}$, во втором $P=R_{x}+F_{m p}$.

Вывод. Таким образом, касательная сила реактивного момента, обеспечивающего равновесие системы, у орудий с пассивными рабочими органами увеличивает тяговое сопротивление необходимое для перемещения рыхлителя, а у рыхлителя - уменьшает.

Ротационные орудия, работающие на принципе движения со скольжением, позволяют снизить тяговое усилие, необходимое для перемещения орудия как за счет снижения скорости резания в сравнении с поступательной, так и изменением направления действия касательной силы реактивного момента. 
Для более широкого использования орудий с ротационными рабочими органами, движущимися со скольжением необходимо идти по пути усовершенствования конструкции рабочих органов.

\section{Список литературы}

1. Бородин Н., Кириченко А. Новый почвообрабатывающий агрегат // Земледелие. - 1982. № 7. - С. 70-71.

2. Синеоков Г.Н Дисковые рабочие органы почвообрабатывающих машин. - М.: Машгиз, 1989. $-86 \mathrm{c}$.

3. Вострухин Н. П. Безотвальная обработка почвы в севообороте. Научные исследования и практическое применение. - Москва: Машиностроение, 2013. - 382 с.

4. Кородецкий А. В. Безотвальная обработка почвы на приусадебном участке: умные агротехнологии. - М.: Питер, 2012. - 826 с.

5. Кородецкий А. Безотвальная обработка почвы на приусадебном участке. Умные агротехнологии. - М.: Питер, 2012. - 128 с.

6. Нарциссов В.П. Научные основы систем земледелия. - М.: Колос, 1982. - 328c.

7. Тенденции развития машин для минимальной обработки почвы: обзор. информ. / Ларюхина Г. Г., Горбачев Ф. П., Пешков А. В., Бугаевский М. П.; Госкомсельхозтехника СССР. ЦНИИТЭИ, - M., 1982. - 12 c.

8. Глухих М.А., Калетин Г.А., Попов А.П. Оптимальное сочетание способов основной обработки почвы. // Земледелие. - 1981. - С. 96.

9. Шварц А. А. Технологии и машины почвозащитной обработки почвы. - Курск: изд-во КГСХА, 2004. - 216 c.

10. Черкасов Г.Н. Перспективы использования нулевых и поверхностных обработок в России // Актуальные агросистемы. - 2015. - №7-8 (31). - С. 8-13.

11 Шварц А.А., Лукин С.Г. Обоснование поверхностной обработки почвы // Актуальные проблемы молодежной науки в развитии АПК: матер. Всерос. национал. науч.-практ. Конф., г. Курск, 11-13 декабря 2019г., ч.1. - Курск: изд-во Курск. ГСХА, 2020. - С. 360-364.

12. Кувайцев В. Н. Машины и орудия для обработки почвы. - М.: Бибком, 2013. - 626 с.

13. Руденко В.Н. Механическая обработка почвы: учеб. пособие. - М.: КноРус, 2016. - 632 с.

14. Кувайцев В. Н. Машины и орудия для обработки почвы. - М.: Бибком, 2013. - 626 с.

15. Старовойтов Н.А. Поверхностная обработка почвы под яровые культуры. // Земледелие. 1981. - № 8. - С. 18-19.

16. Авторское свидетельство SU 1060127 A1. Способ противоэрозионной обработки почвы и устройства для его осуществления: 15.12.1983 / В.И. Курсин , А.А. Шварц.

17. Стрельбицкий В.Ф. Дисковые почвообрабатывающие машины. - М.: Машиностроение, 1978. - $135 \mathrm{c}$.

18. Машины для поверхностной обработки почвы под посев сельскохозяйственных культур / Юнусов Г.С., Майоров А.В., Попов И.И., Кропотов Ю.А. // Аграр. наука Евро-Северо-Востока. Киров, 2012. - С. 50-55.

19. Диско-зубовая коническая борона / Мазитов И.К., Маликов М.М., Гайнанов Х.С., Денисов В.Я. [и др.] // Земледелие. - 1981. - № 3. - С. 58-60.

20. Бараев А.И., Важенин А.Н. Пути совершенствования противоэрозионной техники // Механизация и электрификация социал. сельского хозяйства. - 1973. - № 4. - С. 1-4.

21. Кабаков Н., Жук А. Новый почвообрабатывающий агрегат // Земледелие. - 1982. - № 9. C. $72-73$.

22. Эффективность минимализации обработки серой оподзоленной почвы / Дорошенко Е.Д., Грицай А.Д., Гавриленко В.Г., Коломиец Н.В. // Земледелие. - 1982. - № 8. - С. 20-23.

23. Лежнев Г., Носков П. Орудия для закрытия влаги. Какие лучше? // Земледелие. - 2002. № 2. - С. 20-22.

24. Белевич П.К., Пилецкий А.З. Безотвальная противоэрозионная пахота (на склонах) в увлажненной зоне. // Механизация и электрификация социал. сельск.х-ва. - 1993. - № 1. - С. 1718.

25. Терещенко И.О., Зыков В.А. Эффективность игольчатой бороны-мотыги. // Механизация и электрификация социал.сельск. хоз-ва. - 1975. - № 2. - С. 9-11. 
26. Зиязетдинов Р.Ф. Исследование процессов работы агрегатов с игольчатыми дисками на обработке сельхозкультур: дис ...канд. техн. Наук. - Челябинск, 1985.

27. Кленин Н.И., Попов Н.Ф., Сакун В.А. Сельскохозяйственные машины. - М., 1970. - 456 с.

28. Перспективное направления развития почвообрабатывающих машин / Желиговский В.А., Сизов О.А., Гришин М.Д., Сакун В.А. // Механизация и электрификация соц,сельск,хоз-ва. - 1974. - № 11. - С. 6-9.

29. Яруллин Ф.Ф., Валиев А.Р. Классификация ротационных рабочих органов почвообрабатывающих машин // Аграрная наука XXI века. Актуальные исследования и перспективы: тр. междунар. науч.-практ. конф. / Ин-т механизации и технич. сервиса. - Казань: изд-во Казан. ГАУ, 2015. - С. 131-137.

30. Седнев Н.А. Анализ работы ротационных рабочих органов при движении с затормаживанием. // Тракторы и сельхозмашины. - 1978. - № 10. - С. 18-19.

\section{References}

1. Borodin N., Kirichenko A. Novyj pochvoobrabatyvayushchij agregat. // Zemledelie. - 1982. - № 7. - S. 70-71.

2. Sineokov G.N Diskovye rabochie organy pochvoobrabatyvayushchih mashin. - M.: Mashgiz, 1989. $-86 \mathrm{~s}$.

3. Vostruhin N. P. Bezotval'naya obrabotka pochvy v sevooborote. Nauchnye issledovaniya i prakticheskoe primenenie. - Moskva: Mashinostroenie, 2013. - $382 \mathrm{c}$.

4. Korodeckij A. V. Bezotval'naya obrabotka pochvy na priusadebnom uchastke: umnye agrotekhnologii. - M.: Piter, 2012. - $826 \mathrm{c}$.

5. Korodeckij A. Bezotval'naya obrabotka pochvy na priusadebnom uchastke. Umnye agrotekhnologii. - M.: Piter, 2012. - $128 \mathrm{c}$.

6. Narcissov V.P. Nauchnye osnovy sistem zemledeliya. - M.: Kolos, 1982. - 328s.

7. Tendencii razvitiya mashin dlya minimal'noj obrabotki pochvy: obzor. inform. / Laryuhina G. G., Gorbachev F. P., Peshkov A. V., Bugaevskij M. P.; Goskomsel'hoztekhnika SSSR. CNIITEI, - M., 1982. $-12 \mathrm{~s}$.

8. Gluhih M.A., Kaletin G.A., Popov A.P. Optimal'noe sochetanie sposobov osnovnoj obrabotki pochvy. // Zemledelie. - 1981. - S. 96.

9. SHvarc A. A. Tekhnologii i mashiny pochvozashchitnoj obrabotki pochvy. - Kursk: izd-vo KGSKHA, 2004. - 216 s.

10. CHerkasov G.N. Perspektivy ispol'zovaniya nulevyh i poverhnostnyh obrabotok v Rossii // Aktual'nye agrosistemy. - 2015. - №7-8 (31). - S. 8-13.

11. SHvarc A.A., Lukin S.G. Obosnovanie poverhnostnoj obrabotki pochvy // Aktual'nye problemy molodezhnoj nauki $\mathrm{v}$ razvitii APK: mater. Vseros. nacional. nauch.-prakt. Konf., g. Kursk, 11-13 dekabrya 2019g., ch.1. - Kursk: izd-vo Kursk. GSKHA, 2020. - S. 360-364.

12. Kuvajcev V. N. Mashiny i orudiya dlya obrabotki pochvy. - M.: Bibkom, 2013. $-626 \mathrm{c}$.

13. Rudenko V.N. Mekhanicheskaya obrabotka pochvy: ucheb. posobie. - M.: KnoRus, 2016. $632 \mathrm{c}$.

14. Kuvajcev V. N. Mashiny i orudiya dlya obrabotki pochvy. - M.: Bibkom, 2013. - 626 c.

15. Starovojtov N.A. Poverhnostnaya obrabotka pochvy pod yarovye kul'tury. // Zemledelie. - 1981. - № 8. - S. 18-19.

16. Avtorskoe svidetel'stvo SU 1060127 A1. Sposob protivoerozionnoj obrabotki pochvy i ustrojstva dlya ego osushchestvleniya: 15.12.1983 / V.I. Kursin , A.A. SHvarc.

17. Strel'bickij V.F. Diskovye pochvoobrabatyvayushchie mashiny. - M.: Mashinostroenie, 1978, $135 \mathrm{~s}$.

18. Mashiny dlya poverhnostnoj obrabotki pochvy pod posev sel'skohozyajstvennyh kul'tur / YUnusov G.S., Majorov A.B., Popov I.I., Kropotov YU.A. // Agrar. nauka Evro-Severo-Vostoka. Kirov, 2012. - S. 50-55.

19. Disko-zubovaya konicheskaya borona / Mazitov I.K., Malikov M.M., Gajnanov H.S., Denisov V.YA. [i dr.] // Zemledelie. - 1981. - № 3. - S. 58-60.

20. Baraev A.I., Vazhenin A.N. Puti sovershenstvovaniya protivoerozionnoj tekhniki // Mekhanizaciya i elektrifikaciya social. sel'skogo hozyajstva. - 1973. - № 4. - S. 1-4. 
21. Kabakov N., ZHuk A. Novyj pochvoobrabatyvayushchij agregat // Zemledelie. - 1982. - № 9. S. $72-73$.

22. Effektivnost' minimalizacii obrabotki seroj opodzolennoj pochvy / Doroshenko E.D., Gricaj A.D., Gavrilenko V.G., Kolomiec N.V. // Zemledelie. - 1982. - № 8. - S. 20-23.

23. Lezhnev G., Noskov P. Orudiya dlya zakrytiya vlagi. Kakie luchshe? // Zemledelie. - 2002. - № 2. - S. 20-22.

24. Belevich P.K., Pileckij A.Z. Bezotval'naya protivoerozionnaya pahota (na sklonah) v uvlazhnennoj zone. // Mekhanizaciya i elektrifikaciya social. sel'sk.h-va. - 1993. - № 1. - S. 17-18.

25. Tereshchenko I.O., Zykov V.A. Effektivnost' igol'chatoj borony-motygi. // Mekhanizaciya i elektrifikaciya social.sel'sk. hoz-va. - 1975. - № 2. - S. 9-11.

26. Ziyazetdinov R.F. Issledovanie processov raboty agregatov s igol'chatymi diskami na obrabotke sel'hozkul'tur: dis ...kand. tekhn. Nauk. - CHelyabinsk, 1985.

27. Klenin N.I., Popov N.F., Sakun V.A. Sel'skohozyajstvennye mashiny. - M., 1970. - 456 s.

28. Perspektivnoe napravleniya razvitiya pochvoobrabatyvayushchih mashin / ZHeligovskij V.A., Sizov O.A., Grishin M.D., Sakun V.A. // Mekhanizaciya i elektrifikaciya soc,sel'sk,hoz-va. - 1974. - № 11. - S. 6-9.

29. YArullin F.F., Valiev A.R. Klassifikaciya rotacionnyh rabochih organov pochvoobrabatyvayushchih mashin // Agrarnaya nauka XXI veka. Aktual'nye issledovaniya i perspektivy: tr. mezhdunar. nauch.-prakt. konf. / In-t mekhanizacii i tekhnich. servisa. - Kazan': izd-vo Kazan. GAU, 2015. - S. 131-137.

30. Sednev N.A. Analiz raboty rotacionnyh rabochih organov pri dvizhenii s zatormazhivaniem. // Traktory i sel'hozmashiny. - 1978. - № 10. - S. 18-19.

\section{Сведения об авторах}

\section{Принадлежность к организации}

Шварц Анатолий Адольфович - доктор сельскохозяйственных наук, профессор Федерального государственно бюджетного образовательного учреждения высшего образования «Курская государственная сельскохозяйственная академия», Россия, г. Курск, e-mail: aashwarz.@mail.ru.

Башкирев Анатолий Петрович - доктор сельскохозяйственных наук, профессор Федерального государственно бюджетного образовательного учреждения высшего образования «Курская государственная сельскохозяйственная академия», Россия, г. Курск, e-mail: tmv46@mail.ru.

Таныгин Олег Федорович - кандидат технических наук, децент Федерального государственно бюджетного образовательного учреждения высшего образования «Курская государственная сельскохозяйственная академия», Россия, г. Курск, e-mail: oftanygin@yandex.ru.

Лукин Сергей Геннадьевич - аспирант Федерального государственно бюджетного образовательного учреждения высшего образования «Курская государственная сельскохозяйственная академия», Россия, г. Курск, e-mail: gch.2013@mail.ru.

\section{Author credentials}

\section{Affiliations}

Shvartz Anatoly - Full Doctor of Agricultural Sciences, Professor of Federal State Budgetary Educational Institution of Higher Education "Kursk State Agricultural Academy”, Russia, Kursk, e-mail: aashwarz@mail.ru.

Bashkirev Anatoly Petrovich - Full Doctor of Agricultural Sciences, Professor of Federal State Budgetary Educational Institution of Higher Education "Kursk State Agricultural Academy", Russia, Kursk, e-mail: tmv46@mail.ru.

Tanygin Oleg Fedorovich - Candidate of Technical Sciences, Associate Professor of Federal State Budgetary Educational Institution of Higher Education "Kursk State Agricultural Academy", Russia, Kursk, e-mail: oftanygin@yandex.ru.

Lukin Sergey Gennadievich - graduate student of Federal State Budgetary Educational Institution of Higher Education "Kursk State Agricultural Academy”, Russia, Kursk, e-mail: gch.2013@mail.ru. 